\title{
Broad and potent neutralization of HIV-1 by human-llama fusion antibodies derived from immunized llamas
}

\author{
LE McCoy ${ }^{1 *}$, L Rutten², G Dekkers ${ }^{1}$, C Blanchetot ${ }^{3}$, NM Strokappe $^{4}$, A Forsman-Quigley $^{1}$, MS Seaman ${ }^{5}$, H de Haard ${ }^{3}$, \\ T Verrips ${ }^{4}$, RA Weiss ${ }^{1}$
}

From AIDS Vaccine 2012

Boston, MA, USA. 9-12 September 2012

\section{Background}

Llamas naturally produce heavy chain only antibodies in addition to conventional antibodies. The variable regions of the heavy chain $(\mathrm{VHH})$ demonstrate comparable affinity and specificity for antigens with conventional immunoglobulins. To date, immunizations in human and animal models have yielded only antibodies with limited ability to neutralize human immunodeficiency virus (HIV)-1.

\section{Methods}

A VHH (J3) isolated from a llama multiply-immunized with recombinant trimeric HIV-1 envelope proteins (Env) was found to neutralize 96 of 100 HIV-1 strains, encompassing subtypes $\mathrm{A}, \mathrm{B}, \mathrm{C}, \mathrm{D}, \mathrm{BC}, \mathrm{AE}, \mathrm{AG}, \mathrm{AC}, \mathrm{ACD}, \mathrm{CD}$ and G. Isolation involved expression of $\mathrm{VHH}$ in E. coli and analysis of neutralization ability in TZM-bl reporter cells.

\section{Results}

Newly isolated VHH from multiple immunized llamas also have broad and potent HIV-1 neutralization activity. J3 targets HIV-1 via the CD4-binding site and neutralization is seen when J3 is used in combination with VHH targeting other Env epitopes. VHH-human FC fusion heavychain only antibodies (VHH-FC) have been constructed and J3 activity is not only preserved in this context but enhanced.

\section{Conclusion}

This study shows that experimental immunization with recombinant HIV-1 Env can elicit broad neutralizing

University College London, London, UK

Full list of author information is available at the end of the article heavy-chain only antibodies and supports the development of VHH and VHH-FC as anti-HIV-1 microbicides and therapeutics.

\section{Author details}

${ }^{1}$ University College London, London, UK. ²Biomolecular Imaging, Department Biology, University of Utrecht, Utrecht, the Netherlands. '3arGEN-X BVBA, Ghent, Belgium. ${ }^{4}$ Biomolecular Imaging, Department Biology, Utrecht University, Utrecht, the Netherlands. ${ }^{5}$ Division of Viral Pathogenesis, Beth Israel Deaconess Medical Center, Boston, MA, USA.

Published: 13 September 2012

\section{doi:10.1186/1742-4690-9-S2-P94}

Cite this article as: McCoy et al:: Broad and potent neutralization of HIV-1 by human-llama fusion antibodies derived from immunized llamas. Retrovirology 2012 9(Suppl 2):P94.
Submit your next manuscript to BioMed Central and take full advantage of:

- Convenient online submission

- Thorough peer review

- No space constraints or color figure charges

- Immediate publication on acceptance

- Inclusion in PubMed, CAS, Scopus and Google Scholar

- Research which is freely available for redistribution

Submit your manuscript at www.biomedcentral.com/submit
C Biomed Central 